Anna Jaroszewska

Uniwersytet Warszawski

a.jaroszewska@uw.edu.pl

\title{
ROZWÓJ ZAWODOWY NAUCZYCIELI JĘZYKÓW OBCYCH SZKÓŁ PAŃSTWOWYCH NIŻSZEGO SZCZEBLA - MOŻLIWOŚCI, ŹRÓDŁA MOTYWACJI I DEMOTYWACJI
}

\author{
The professional development of foreign language teachers \\ in primary and lower secondary state schools \\ - possibilities, sources of motivation and demotivation
}

The professional development of teachers is associated with increased specialized competence and professional advancement, which usually correlate with a specific level of intrinsic and extrinsic motivation. The vagaries of Polish education and its contemporary image are not always conducive to such development and generate situations, or circumstances, which demotivate some teachers, despite the availability of many possibilities for development. This article aims to present a catalogue of options for teacher development. It discusses selected issues relating to the motivation and demotivation of foreign language teachers employed in the general public education system, in particular primary and lower secondary schools, with regard to engaging in professional development.

Keywords: teaching foreign languages, professional development of teachers, motivation and demotivation towards professional development, Polish education system.

Słowa kluczowe: nauczanie języków obcych, rozwój zawodowy nauczycieli, motywacja i demotywacja w rozwoju zawodowym, polski system edukacyjny 


\section{Wprowadzenie}

Rozwój zawodowy nauczycieli można uznać za pochodną przyrostu ich kompetencji specjalistycznych oraz awansu zawodowego, które zwykle korelują z określonym poziomem motywacji własnej i wzbudzonej zewnętrznie. Meandry polskiej oświaty nie zawsze sprzyjały takiemu rozwojowi. Pomimo przyrostu systemowych możliwości, napór czynników utrudniających ów rozwój może niepokoić. Celem artykułu jest przedstawienie katalogu tych możliwości oraz zwrócenie uwagi na wybrane zagadnienia dotyczące motywacji i demotywacji do rozwoju zawodowego nauczycieli języków obcych zatrudnionych w publicznym systemie kształcenia, w szczególności w szkołach podstawowych i gimnazjach ${ }^{1}$.

Miarą sukcesu edukacyjnego - także w nauczaniu/uczeniu się języków obcych - jest stopień realizacji przyjętych celów kształcenia (Pfeiffer, 2001: 97-98). Niestety, choć cele te i warunki ich realizacji w dokumentach programowych polskiej oświaty zostały określone dość precyzyjnie, a i w świetle współczesnych teorii glottodydaktycznych nie budzą one większych zastrzeżeń, liczne raporty i ekspertyzy edukacyjne oraz doświadczenia i własne obserwacje autorki dostarczają przekonujących danych o tym, że na poziomie edukacji obowiązkowej, przede wszystkim w szkołach publicznych niższego szczebla, w dalszym ciągu występują problemy z realizacją tych celów, podobnie jak i z zapewnieniem odpowiednich warunków dla ich realizacji. Przyczyny tego są różne. Tymczasem, jak stwierdza W. Pfeiffer (2001: 198), „przyswojenie języka obcego $w$ warunkach szkolnych to proces wieloletniej, systematycznej, metodycznie i organizacyjnie dobrze zaprogramowanej nauki. Na końcowy sukces ma wpływ wiele różnorodnych i wzajemnie warunkujących się czynników. Niektóre z nich bywają absolutyzowane, a nawet demonizowane [...]. Pomijając jednak te skrajne przypadki, w praktyce stwierdzić można różne akcentowanie poszczególnych czynników efektywności. I tak istnieją opinie, że jedynie pilność, wytrwałość i elastyczność uczniów, a także oczywiście ich motywacja, zapewnić mogą końcowy sukces. Inni twierdzą, że najważniejszą rolę spełnia nauczyciel odpowiedzialny za organizację i przebieg procesów nauczania i uczenia się. Nie brak zwolenników opinii, że decydujący wpływ na sukces nauczania mają przede wszystkim dobre warunki łącznie $z$ dobrymi

\footnotetext{
${ }^{1}$ Fragmenty niniejszych rozważań ukazały się już na łamach elektronicznej publikacji pt. „Budowanie przyjaznego środowiska wspierającego efektywną naukę języków obcych. Poradnik nie tylko dla nauczycieli" (Jaroszewska, 2014), wydanej pod auspicjami Ośrodka Rozwoju Edukacji i Centrum Kształcenia Nauczycieli Języków Obcych i Edukacji Europejskiej Uniwersytetu Warszawskiego, jednak bez zgody autorki zostały wówczas w sposób istotny ocenzurowane, co skłania do ich ponownej prezentacji w pełnym brzmieniu.
} 
materiałami nauczania. Zauważyć trzeba, że wszystkie te opinie mają swoje racje i uzasadnienie. Nietrudno jednak o konsens, jeśli stwierdzę, że na końcowy sukces w procesie nauczania i uczenia się języka obcego wpływ mają wszystkie zaangażowane w tym procesie czynniki".

Wypowiedź tę warto dopełnić tezą, która system glottodydaktyczny obrazuje w kategoriach spójnej całości - trwałego łańcucha wzajemnych relacji, oddziaływań i zależności między wszystkimi uczestnikami procesu edukacyjnego. Pomimo długoletnich reform oświatowych i zauważalnych pozytywnych przemian, polski system nauczania języków obcych w dalszym ciągu pozostaje rozczłonkowany i nader często jeszcze koncentruje się wyłącznie na nauczycielu i jego uczniach, odpowiedzialnością za efekty kształcenia obarczając głównie tego pierwszego. A przecież powinien mieć on charakter wielopodmiotowy i wielokontekstowy. Odwołując się do koncepcji przyjaznego środowiska kształcenia - w rozumieniu zarówno uczenia się, jak i nauczania - można stwierdzić wprost, że, aby podnieść jego efektywność, należy przeprowadzić szeroko zakrojone działania naprawcze i spajające sześć głównych poziomów tego systemu: 1) prawodawstwo; 2) organizację i wsparcie logistyczne szkół; 3) edukację formalną; 4) edukację pozaformalną; 5) nieformalne uczenie się; 6) politykę kadrową. I to właśnie poziom ostatni - zgodnie z tematem niniejszego opracowania - będzie przedmiotem uszczegółowionej analizy.

\section{Rozwój zawodowy nauczycieli języków obcych - podstawy prawne i teoretyczne}

Zakres obowiązków oraz kwalifikacji, którymi winni się legitymować nauczyciele języków obcych, w tym przypadku nauczający w klasach I-III i IV-VI szkół podstawowych oraz w gimnazjach, wynika wprost z zapisów obowiązujących aktów normatywnych, których podstawowy wykaz zamieszczono w końcowym zestawieniu bibliograficznym.

Zważywszy, że w niniejszym artykule nie przewidziano miejsca ani na referowanie treści aktów prawnych, ani tym bardziej na studiowanie uniwersyteckich programów kształcenia, należy wyjaśnić, że kompetencje zawodowe nauczycieli języków obcych będą tu rozumiane jako sprzężone ze sobą: wiedza merytoryczna, wiedza i doświadczenie pedagogiczne, inne umiejętności oraz cechy osobowościowe nauczyciela, pozwalające mu profesjonalnie nauczać i wychowywać swoich uczniów. W dalszej kolejności warto skierować uwagę na kompleksowe opracowanie tej problematyki, które w roku 2004 poczyniła Elżbieta Zawadzka w swojej monografii pt. Nauczyciele języków obcych w dobie przemian. Ono bowiem przynosi odpowiedź na to, jak wygląda i jak wyglądać powinien docelowy poziom nauczycielskich kompetencji w przedmiotowym 
zakresie; tym samym dookreśla kierunki rozwoju polskiego systemu kształcenia nauczycieli języków obcych, a w ślad za tym i pedeutologii polskiej obejmującej tę grupę zawodową (Gębal, 2013: 109-n). Na podstawie poczynionych ustaleń - tu w uproszczeniu - można przyjąć, że nauczyciel języków obcych, w drodze wykształcenia uniwersyteckiego, ale i następującego po nim ustawicznego doskonalenia zawodowego, które trzeba uznać za nieodłączny atrybut tego zawodu, powinien nabywać, wykształcać, wzbudzać i rozwijać w sobie szereg kompetencji, które pozwolą mu na jednoczesne realizowanie $\mathrm{w}$ ramach pracy nauczycielskiej roli: „eksperta”, „wychowawcy”, „organizatora”, „moderatora”, „doradcy”, „pośrednika kulturowego”, „ewaluatora”, „innowatora”, „badacza” oraz „refleksyjnego praktyka”. Z tej perspektywy do katalogu najważniejszych kompetencji należy zaliczyć: kompetencje merytoryczne, w tym kompetencje językowe, kompetencje komunikacyjne, kompetencje psychologiczno-pedagogiczne, kompetencje diagnostyczne, kompetencje w zakresie planowania i projektowania, kompetencje dydaktyczno-metodyczne, kompetencje medialne i techniczne, kompetencje krajo- i kulturoznawcze, kompetencje wychowawcze oraz moralne, a także kompetencje autoedukacyjne i innowacyjno-kreatywne (por. Jaroszewska, 2009).

Zakładając, iż zakres funkcji i ról nauczycieli języków obcych, jak również istota wyżej wymienionych kompetencji są dobrze znane w środowisku glottodydaktyków i z pewnością podczas Gdańskiej Konferencji PTN (2014), poświęconej kształceniu i doskonaleniu nauczycieli języków obcych, zagadnienia te były omawiane wielokrotnie, dalsze rozważania skoncentrowane zostaną nie tyle na multiplikowaniu ich opisów i interpretacji, co na wskazaniu obszarów i możliwości ich kształcenia przez i u nauczycieli języków obcych praktykujących w szkołach publicznych niższego szczebla, a więc już na etapie właściwej pracy nauczycielskiej.

Nim jednak przedmiotowa analiza zostanie poczyniona, warto nadmienić, że - i to wynika z tezy postawionej na wstępie - rozwój zawodowy nauczycieli języków obcych nie przebiega w próżni i nie jest zależny wyłącznie od nich samych, lecz jest uwarunkowany rozmaitymi czynnikami natury przedmiotowej i podmiotowej, zakorzenionymi i wyłaniającymi się zarówno w najbliższym otoczeniu zawodowym, a później w szerzej rozumianym środowisku szkolnym, jak i w sferach formalno-prawnej i życia prywatnego. Na dynamikę, kierunki i jakość tego rozwoju niebagatelny wpływ ma również faza kariery zawodowej, w jakiej w danej chwili znajduje się nauczyciel. Siłą rzeczy są to jednocześnie determinanty przesądzające o określonym poziomie motywacji nauczyciela - tak do rzetelnego wypełniania obowiązków wynikających ze statusu zatrudnienia, jak i do działań zmierzających do tego, aby stale rozwijać swój „warsztat pracy”, a tym samym rozszerzać zakres swoich kompetencji - 
tu w rozumieniu obszaru praw i obowiązków, odpowiedzialności oraz osobistych wpływów na system glottodydaktyczny².

Przechodząc do meritum, należy wskazać na podstawowe, ogólnodostępne formy doskonalenia zawodowego nauczycieli języków obcych, których ci, podobnie zresztą jak kadry zarządzające zasobami ludzkimi w szkole, winni być w pełni świadomi i do korzystania z których należy ich zachęcać na wszelkie możliwe sposoby.

\section{Typologia form doskonalenia zawodowego nauczycieli języków obcych}

W szkołach powinien być zorganizowany, i tak się zwykle dzieje, wewnątrzszkolny system doskonalenia nauczycieli (WDN), obejmujący wszystkich członków Rady Pedagogicznej, w tym nauczycieli języków obcych. W ramach tego systemu, którego zasady funkcjonowania precyzuje stosowny regulamin ustanawiany wewnętrznie, prowadzona jest działalność mająca na celu diagnozę potrzeb i oczekiwań nauczycieli w zakresie podniesienia bądź uzupełnienia ich kwalifikacji zawodowych, co ma zmierzać do: 1) rozwoju kompetencji dydaktycznowychowawczych nauczycieli, 2) doskonalenia metod ich pracy, 3) wzmocnienia autonomii działania i rozwoju pożądanych cech osobowości, 4) poprawienia komunikacji i współpracy w Radzie Pedagogicznej lub w relacjach nauczyciele - rodzice, a w konsekwencji 5) do ogólnej poprawy jakości pracy szkoły.

Wewnątrzszkolny system doskonalenia nauczycieli obejmuje: doskonalenie indywidualne (samokształcenie), doskonalenie wewnętrzne (realizowane na terenie szkoły) oraz doskonalenie zewnętrzne (poza miejscem pracy). W obszarze tym można wyróżnić następujące podstawowe działania ukierunkowane na rozwijanie szeroko rozumianych kompetencji nauczycielskich: szkoleniowe rady pedagogiczne; szkoleniowe posiedzenia zespołów samokształceniowych; warsztaty; narady; konferencje metodyczne; seminaria; lekcje otwarte; kursy kwalifikacyjne; studia podyplomowe; prace opiekunów stażu; prace zespołów przedmiotowych; prelekcje przygotowane przez nauczycieli; dzielenie się wiedzą z innymi nauczycielami; spotkania ze specjalistami. Doskonalenie w powyższych formach ma zwykle charakter dobrowolny. W sytuacjach uzasadnionych może być obligatoryjne i obejmować konkretnego nauczyciela, a niekiedy wszystkich członków Rady Pedagogicznej. Następuje bądź to na wniosek zainteresowanego nauczyciela, bądź to poprzez skierowanie go na stosowny kurs przez dyrektora szkoły po uprzednim zasięgnięciu

\footnotetext{
2 Por. Model dynamiki cyklu kariery nauczyciela wg Ralpha Fesslera i Judith C. Christensen (1992: 36 za: Day, 2004: 104).
} 
opinii Rady Pedagogicznej, w szczególności koordynatora odpowiedzialnego za organizację WDN, który bywa też nazywany liderem WDN.

Trzeba wyraźnie podkreślić, że to właśnie od sprawności działania lidera WDN i podlegającego mu zespołu, jak również od przychylności dyrektora szkoły, a także organu prowadzącego, w dużej mierze warunkującego istnienie takiego systemu wsparciem finansowym, zależy stały rozwój kadry szkolnej, a wraz z nim przyjazne środowisko kształcenia - tak uczniów, jak i nauczycieli. Innym istotnym czynnikiem jest świadomość nauczycieli, w tym ich gotowość do doskonalenia się w zawodzie. Może to być doskonalenie z zakresu szeroko rozumianej psychopedagogiki, jak i ukierunkowane typowo na rozwój kompetencji przedmiotowych, np. językowych i/lub metodycznych. W pierwszym przypadku paleta tematyczna dostępnych kursów i szkoleń jest niezwykle bogata i może dotyczyć takich obszarów problemowych, jak:

- aspekty zarządzania procesem edukacyjnym (np. planowanie, organizowanie, motywowanie, ewaluacja);

- współpraca z uczniami, nauczycielami, rodzicami/opiekunami itd.;

- warsztat pracy nauczyciela (np. diagnozowanie i ocenianie, metody i techniki nauczania, projekty edukacji pozaformalnej);

- aspekty psychologiczne i pedagogiczne (motywacja, autonomia, stres, agresja, wypalenie zawodowe, specjalne potrzeby edukacyjne itd.).

Także Powiatowe Ośrodki Doskonalenia Nauczycieli, Regionalne Ośrodki Doskonalenia Nauczycieli, Wojewódzkie Ośrodki Doskonalenia Nauczycieli oraz Instytuty Rozwoju Edukacji mają również w swojej ofercie - warto dodać, że niekiedy objętej wsparciem z grantów właściwych miejscowo Kuratorów Oświaty bądź Ministerstwa Edukacji Narodowej - seminaria, konsultacje, warsztaty, szkolenia, kursy językowe, kursy e-learningowe oraz kwalifikacyjne pedagogiczno-metodyczne dla nauczycieli języków obcych. Przykładem niech będą tu kursy i szkolenia o następującej tematyce:

- "Niekonwencjonalne metody nauczania języków obcych";

- „Praca z dzieckiem ze specyficznymi trudnościami w uczeniu się na lekcjach języków obcych";

- "Style uczenia się a techniki pracy z uczniem na lekcjach języka obcego”;

- „Jak tworzyć i podtrzymywać motywację do nauki języka obcego?";

- „Dobór, tworzenie i adaptacja materiałów dodatkowych w nauczaniu języka angielskiego, czyli zaprzyjaźnij się z Internetem";

- „Praca metodą projektu na lekcjach języka angielskiego/niemieckiego”;

- „Konstruowanie nowych i modyfikacja dostępnych programów nauczania w zakresie języków obcych";

- „Wykorzystanie twórczego potencjału uczniów w nauce języków obcych”; 
- „Nowa rola nauczyciela a współpraca z rodzicami w nauczaniu/uczeniu się języka angielskiego";

- „Elementy kulturowe w nauczaniu/uczeniu się języka angielskiego".

Godnym polecenia ośrodkiem, który w skali krajowej rozwija sieć wsparcia w zakresie doskonalenia zawodowego, m.in. nauczycieli języków obcych, jest Ośrodek Rozwoju Edukacji (ORE). Z przykładowych tematów warsztatów i szkoleń, jakie realizował bądź realizuje wymienić warto:

- „Wykorzystanie tablicy interaktywnej i tabletów w nauczaniu języka angielskiego";

- "CLIL - włączanie języka obcego w edukację wczesnoszkolną";

- „Wprowadzenie elementów kultury w nauce języka niemieckiego ćwiczenia i formy pracy z dziećmi";

- "Kurs języka hiszpańskiego w ramach programu Europrof";

- „Kino na lekcjach francuskiego”;

- „Edukacja językowa w programie "Uczenie się przez całe życie»";

- "Metodyka od "A» do «Я»";

- „Wykorzystywanie bajek na lekcjach języka niemieckiego do wzrostu motywacji u uczniów";

- „Jak pracować z najnowszymi materiałami do nauczania języka niemieckiego w szkole podstawowej";

- „Europejskie Portfolio Językowe - Od autonomicznego nauczyciela do autonomicznego ucznia".

W poczet bogatej oferty różnego typu form dokształcania nauczycieli języków obcych ${ }^{3}$, jaką oferuje ORE, należy włączyć ponadto konferencje tematyczne, jak np.: „Uczniowie z mniejszości narodowych w polskiej szkole”, „Motywacja w edukacji językowej”, „Wielojęzyczność i wielokulturowość w polskiej szkole", ale także prace programowe w ramach takich projektów strategicznych, jak: „DELFORT”, „ECML - Punkt Kontaktowy”, „Metoda LdL”, „Nauczanie dwujęzyczne”, "Szkoła wobec wyzwań migracyjnych”, „Wczesnoszkolne nauczanie języków obcych”, "Nowoczesne technologie”, „Wspieranie polityki językowej Rady Europy”, „Zmieniająca się szkoła”, ,"Współpraca polsko-gruzińska, projekt "One są wśród nas»". Owocują one licznymi opracowaniami, tak o charakterze teoretycznym lub w postaci diagnoz edukacyjnych, jak i typowo użytkowymi publikacjami, np. scenariuszami zajęć, modelami pracy itd. Materiały te są udostępniane nieodpłatnie w Bibliotece Cyfrowej ORE lub bezpośrednio na stronie internetowej ośrodka.

\footnotetext{
${ }^{3}$ Podobnie jak inne Ośrodki Doskonalenia Nauczycieli, tak i ORE swoją ofertę kieruje do szerokiego grona kadry szkół różnych szczebli i typów kształcenia, także do kadry zarządzającej oświatą.
} 
Wśród działów tematycznych, wyszczególnionych na stronie internetowej ORE ${ }^{4}$, z których mogą korzystać nauczyciele, znalazły się tak istotne zagadnienia, jak: „Rozwój Szkół i Placówek”, „,Resocjalizacja i Socjoterapia”, „Specjalne Potrzeby Edukacyjne”, „Wychowanie i Profilaktyka”, „Rozwój Kompetencji Językowych”, „Informacja i Promocja”, „Rozwój Kompetencji Społecznych i Obywatelskich", „Adaptacja podręczników”; „Biblioteka Cyfrowa”, „Medioteka Edukacyjna”, „Internetowy Serwis Edukacyjny”, „e-Learning w Szkole - Infoteka”.

W strukturach ORE publikowane są ponadto czasopisma "Języki Obce w Szkole" ${ }^{\prime}$ i "Trendy - internetowe czasopismo edukacyjne”, będące platformą wymiany myśli o charakterze naukowym, popularnonaukowym oraz dydaktyczno-metodycznym, z których warto korzystać, wzbogacając zarówno swoją wiedzę, jak i czerpiąc inspirację.

Pozostając przy publikacjach edukacyjnych, poza zalecaną najnowszą literaturą przedmiotu, należy przywołać także inne czasopisma, które już na stałe wpisały się w system (samo)doskonalenia nauczycieli języków obcych (i nie tylko). Należą do nich m.in.: „Edukacja i Dialog”, „E-mentor”, „Meritum. Mazowiecki Kwartalnik Edukacyjny”, "Modern English Teacher", "The Teacher's Magazine”, „English Teachingprofessional”, „Le Francaisdans le Monde”, „Frühes Deutsch”, „Fremdsprache Deutsch”, „Hallo Deutschlehrer”.

Za ważne źródło wiedzy, wspomagające rozwój zawodowy nauczycieli języków obcych, należy też uznać informacje i materiały zamieszczane na stronie i tematycznych podstronach Ministerstwa Edukacji Narodowej oraz Centralnej Komisji Egzaminacyjnej. Wiele ciekawych informacji, a jednocześnie materiałów wspomagających rozwój, można pozyskać śledząc internetowe serwisy edukacyjne, np.: Portal społeczności oświatowej „Oświata”, Serwis edukacyjny „Profesor”, Polski portal edukacyjny „Interkl@sa”, Portal „edulandia.pl”, Portal wiedzy dla nauczycieli „Scholaris”, „Portal oświatowy”, Portal „Edukacja-Internet-Dialog”7.

Cenne i inspirujące mogą okazać się odwiedziny serwisów internetowych poszczególnych projektów edukacyjnych realizowanych w wymiarze europejskim, takie jak: European Profiling Grid (EPG), FREPA, Europass, Eurydice,

\footnotetext{
${ }^{4}$ Por. http://www.ore.edu.pl/

${ }^{5}$ Na szczególną uwagę zasługuje Internetowy Serwis Edukacyjny ORE, będący bardzo użyteczną wyszukiwarką zapewniającą dostęp do ogólnopolskiej bazy różnego typu form doskonalenia kadry szkolnej.

${ }^{6}$ Obecnie „Języki Obce w Szkole” wydawane są pod auspicjami Fundacji Rozwoju Systemu Edukacji.

${ }^{7}$ Choć trzeba przyznać, że niekiedy merytoryczna jakość prezentowanych tam materiałów budzi wątpliwości.
} 
poszczególnych programów wchodzących w skład programu „Uczenie się przez całe życie" czy szeregu innych realizowanych w Polsce w ramach Europejskiego Funduszu Społecznego i Programu Kapitał Ludzki, a owocujących nie tylko różnorodną gamą tzw. dobrych praktyk, lecz także licznymi konferencjami, szkoleniami, warsztatami. Przy tej okazji warto zwrócić uwagę na nowy unijny program edukacyjny Erasmust, który zastąpił program „Uczenie się przez całe życie" i będzie realizowany w latach 2014-2020. Odsyłając do strony internetowej programu należy jedynie zaznaczyć, że jego zadaniem będzie m.in. wspieranie rozwoju kadry oświatowej - tak poprzez krajowe projekty szkoleniowe, jak i w ramach wyjazdów zagranicznych.

Bogatą ofertę doskonalenia zawodowego nauczycieli języków obcych zapewniają także różnego typu placówki komercyjne, które funkcjonują niemal w każdym większym mieście. Interesująca jest również oferta zagranicznych instytutów języka i kultury. Dla nauczycieli języków obcych organizują one kursy językowe, kwalifikacyjne i doskonalące w Polsce i zagranicą, warsztaty, seminaria, konferencje, udostępniają bezpłatne materiały internetowe. Opis szczegółowej oferty poszczególnych ośrodków można znaleźć na ich stronach internetowych. Bogatą ofertę szkoleniową, głównie z zakresu metodyki nauczania oraz zmian w systemie prawnym, proponują również liczne i bardzo aktywne wydawnictwa edukacyjne, dodatkowo umożliwiając korzystanie z rozbudowanych serwisów internetowych obsługiwanych przez ekspertów danego szczebla kształcenia. Ważną rolę odgrywają nauczycielskie i naukowe towarzystwa, które, np. przy okazji konferencji naukowych, organizują również warsztaty metodyczne dla nauczycieli języków obcych. Uwagę zwracają nowe programy kształcenia w uczelniach wyższych, które, starając się podążać za współczesną myślą glottodydaktyczną i jednocześnie dostrzegając potrzeby rynku, proponują coraz bardziej wyspecjalizowane kursy i studia podyplomowe, pozwalające nauczycielom podnieść swoje kompetencje bądź nawet przekwalifikować się.

Warto przywołać również często bagatelizowane, a nie mniej ważne, możliwości własnego rozwoju nauczyciela, w szczególności w zakresie podniesienia kompetencji merytorycznych (językowych i międzykulturowych), poprzez:

- korzystanie z wszelkich dostępnych mediów obcojęzycznych;

- aktywny kontakt z rodzimymi użytkownikami danego języka, który staje się możliwy nie tylko dzięki wyjazdom zagranicznym, ale i dzięki tym mediom;

- korzystanie z obcojęzycznych audiobooków;

- uczestnictwo w kursach e-learningowych;

- audiokursy językowe;

- sięganie do literatury obcojęzycznej, niekoniecznie dydaktycznie profilowanej; 
- pracę z „Europejskim Portfolio Językowym” oraz „Autobiografią Spotkań Międzykulturowych";

- wymianę wiedzy i doświadczeń z innymi nauczycielami języków obcych.

\section{4. Źródła motywacji i demotywacji do rozwoju zawodowego nauczycieli języków obcych, czyli o ewaluacji ich działalności dydaktyczno- wychowawczej}

Jak wynika z zapisów przywoływanej już Ustawy Karta Nauczyciela czy Rozporzq̨dzenia Ministra Edukacji Narodowej z dnia 7 października 2009 r. w sprawie nadzoru pedagogicznego (Dz.U. nr 168 z 2009r., poz. 1324 z późn. zm.) ${ }^{8}$, każdy nauczyciel, także nauczyciel języka obcego, podlega okresowej ocenie. Ocena ta może być prowadzona w ramach ewaluacji i kontroli wewnętrznej, jak również mieć charakter zewnętrzny. Może być ona inicjowana na wniosek i przy współudziale każdego z uczestników procesu edukacyjnego - z zainteresowanym nauczycielem, jego uczniami i ich rodzicami/opiekunami włącznie. Może to być ocena wpisująca się w plan ewaluacji szkoły, a więc podsumowująca przygotowanie i aktywność nauczyciela w trzech podstawowych, wyznaczonych rozporządzeniem obszarach: 1) efekty działalności dydaktycznej, wychowawczej i opiekuńczej oraz innej działalności statutowej szkoły lub placówki; 2) procesy zachodzące w szkole lub placówce; 3) funkcjonowanie szkoły lub placówki w środowisku lokalnym, w szczególności w zakresie współpracy z rodzicami/opiekunami uczniów. Może też odnosić się wyłącznie do konkretnego nauczyciela - jego osiągnięć, postaw, aktywności itd.

Jak wynika z zapisów prawnych, każda taka ocena, niezależnie, czy ukierunkowana na placówkę czy na poszczególnych członków kadry dydaktycznej, powinna pociągać za sobą efekt wspomagania, przez które należy rozumieć „działania organu sprawującego nadzór pedagogiczny mające na celu inspirowanie i intensyfikowanie w szkołach i placówkach procesów służących poprawie i doskonaleniu ich pracy, ukierunkowanych na rozwój uczniów i wychowanków" (Dz.U. nr 168 z 2009r., poz. 1324 z późn. zm.). Należałoby dopowiedzieć: a zatem także na rozwój kadry, m.in. nauczycieli języków obcych. Do takiego rozwoju mogą się przyczynić jednak nie tylko oceny prowadzone w ramach nadzoru pedagogicznego, lecz również działalność zmierzająca do samooceny nauczyciela. Poza prowadzeniem własnego dossier, nauczyciel powinien

\footnotetext{
${ }^{8}$ Dopełnieniem tych zapisów jest Rozporzq̨dzenie Ministra Edukacji Narodowej z dnia 21 grudnia 2012 r. w sprawie kryteriów i trybu dokonywania oceny pracy nauczyciela, trybu postępowania odwoławczego oraz składu i sposobu powoływania zespołu oceniajqcego (Dz.U. nr 0 z 2012r., poz. 1538).
} 
więc opracować stosowne narzędzia, dzięki którym będzie mógł uzyskać informacje na swój temat - także od uczniów i ich rodziców/opiekunów. Do gromadzenia tych danych nauczyciel może wykorzystywać: 1) cykliczne ankiety ewaluacyjne wypełniane przez uczniów, 2) rozmowę z uczniami na forum klasy, 3) klasową księgę skarg i zażaleń, 4) ankiety oceniające dystrybuowane wśród rodziców/opiekunów uczniów, 5) otwartą rozmowę z rodzicami/opiekunami uczniów. Wprowadzenie takich narzędzi może wydawać się kontrowersyjne i dla nauczyciela trudne, jednak jednocześnie - z punktu widzenia budowania świadomości na swój temat - są to narzędzia godne uwagi.

Każda ocena nauczyciela powinna dostarczać szczegółowych informacji na temat pożądanego kierunku zmian, jakie winien on wprowadzić do swojego warsztatu pracy. Aby można było mówić o skuteczności takiej oceny i w dalszej kolejności o jej ewaluacyjnym charakterze (w pewnym sensie naprawczym), należy taką ocenę dopełnić systemem nagród i kar. Koncentrując się na kwestii pierwszej, można przyjąć, że system taki powinien uwzględniać działania motywacyjne podejmowane przede wszystkim przez dyrektora szkoły, a polegające na:

1) okazywaniu zainteresowania pracą nauczyciela, jak również sferą jego życia osobistego i uwzględnianiu rodzących się na tym tle potrzeb;

2) okazywaniu zainteresowania zdaniem oraz pomysłami nauczyciela i, jeżeli jest to uzasadnione, wdrażaniu ich do praktyki;

3) obdarzaniu nauczyciela zaufaniem i wspieraniu jego autonomii w ramach przysługujących mu kompetencji;

4) dawaniu nauczycielowi nagród w postaci:

- pochwał;

- wyróżnień;

- dyplomów;

- nagród pieniężnych (z budżetu szkoły, na podstawie złożonych wniosków o przyznanie nagrody burmistrza dzielnicy, prezydenta miasta, kuratora oświaty, ministra edukacji narodowej);

- składając wnioski o odznaczenie nauczyciela medalem Komisji Edukacji Narodowej.

5) zachęcaniu nauczyciela do rozwoju i wspieraniu go w tym poprzez, np.:

- finansowanie bądź współfinansowanie studiów, kursów, szkoleń itd.;

- pokrywanie kosztów dojazdów nauczyciela na szkolenie;

- udzielanie urlopu szkoleniowego/dni wolnych na poczet udziału w szkoleniu;

- przyznawaniu dodatku finansowego z tytułu podniesienia kwalifikacji. 
Wobec powyższego warto postawić pytanie: Jaka jest rzeczywistość polskich szkół publicznych i realne problemy nauczycieli języków obcych, które mogq przesqqdzać o ich zaburzonej motywacji do własnego rozwoju zawodowego?

W wielu polskich szkołach nadal są odczuwalne braki kadrowe lub w wykształceniu kadry. Wątpliwości budzi również zaplecze logistyczne szkół, zwłaszcza tych zlokalizowanych na tzw. obszarach defaworyzowanych. Godzi to przede wszystkim w ofertę programową, objawia się zbyt dużym zagęszczeniem klas, koniecznością nauczania w systemie dwuzmianowym, co w szczególności utrudnia pracę na poziomie kształcenia wczesnoszkolnego, choć na niedogodności narażone są także wyższe roczniki uczniów. Jednocześnie przekłada się to na obraz pracowni językowych, które, o ile szkoła w ogóle takowe posiada, nie zawsze są wyposażone w nowe pomoce i rekwizyty, w tym dostęp do mediów, pozwalających nauczycielowi na wykorzystanie pełni potencjału uczniów, ale i własnego. Nauczyciele języków obcych nader często są więc zdani na własną wiedzę, doświadczenie i inwencję, co nie oznacza, że są gotowi ponosić dodatkowe koszty uatrakcyjniania prowadzonych przez siebie zajęć. Trudno się temu dziwić, tym bardziej że na wystawianą im ocenę zasadniczy wpływ mają nie tyle ich zaangażowanie i pomysłowość czy fascynacja, jaką wzbudzają u swoich uczniów, co wymierne wyniki z kolejnych egzaminów, którym są poddawani ich uczniowie, a także ogólny poziom zdawalności/drugoroczności.

Brak wsparcia ze strony dyrektora szkoły, niechęć do współpracy wyrażana przez innych, równie obciążonych nauczycieli, brak zaangażowania rodziców/opiekunów prawnych uczniów, problemy pojawiające się w klasach integracyjnych oraz ogólnodostępnych, w których, mimo obecności uczniów z niepełnosprawnością, brakuje nauczyciela wspomagającego ${ }^{9}$, to kolejne utrudnienia zbyt często pojawiające się na drodze do osiągnięcia przez nich sukcesu - osobistego oraz przejawiającego się w pozytywnych wynikach i postawach uczniów.

Konkludując, można uznać, że ustawowe zapisy precyzyjnie regulują kwestie dotyczące konsolidacji potencjału szkoły - jako instytucji otwartej, współpracującej z otoczeniem, angażującej się nie tylko w nauczanie, ale i w wychowywanie,

${ }^{9}$ Włączenie w skład osobowy klasy szkoły ogólnodostępnej jednego lub dwóch uczniów z niepełnosprawnością bądź innego typu deficytem w świetle przepisów prawa nie czyni jej jeszcze klasą integracyjną/specjalną i nie rodzi obowiązku ograniczenia liczby uczniów $w$ takiej klasie oraz dodatkowo zatrudnienia na jej potrzeby nauczyciela wspomagającego bądź innego, o specjalistycznym przeszkoleniu. Choć cel integracji jest i w tym przypadku celem szczytnym, to nierzadko nauczyciel pozbawiony wsparcia, często nieposiadający przygotowania do pracy z uczniami o specjalnych potrzebach, nie jest w stanie podołać takiemu wyzwaniu, co okazuje się szkodliwe nie tylko dla komfortu jego pracy, ale przede wszystkim dla uczniów - tak tych z niepełnosprawnością/deficytami, jak i pozostałych. 
w zaspokajanie potrzeb uczniów, także tych specjalnych, w końcu w rozwiązywanie problemów, które dotykają i uczniów, i nauczycieli, niezależnie od przedmiotu czy poziomu kształcenia. Nauczyciele języków obcych oraz ich uczniowie w świetle tych zapisów nie są defaworyzowani czy w inny sposób pokrzywdzeni. Szkolna rzeczywistość nie zawsze jest jednak zgodna z tymi zapisami. O ile zaangażowanie w pracę i poziom kompetencji zawodowych nauczycieli języków obcych w dużej mierze wynikają z ich autonomii, dotychczasowego wykształcenia i doświadczeń oraz dbałości o samorozwój czy w końcu z cech osobowości i postaw, które w tym przypadku zwykło się nazywać powołaniem do zawodu, to wspomniane problemy logistyczno-materiałowe, kontynuacji kursu na wyższym szczeblu kształcenia, liczebności klas, podziału na grupy zaawansowania czy choćby wygospodarowania dodatkowego czasu, np. na pracę projektową, pozostają w gestii dyrektorów szkół, samorządów gminnych oraz organów pełniących nadzór pedagogiczny nad placówką. Na szczeblu zarządzania oświatą perspektywa ucznia i nauczyciela z ich realnymi potrzebami traci na znaczeniu, istotny staje się rachunek ekonomiczny, który bardzo rzadko, szczególnie w dobie niżu demograficznego, jest w szkołach publicznych dodatni.

Zyskujący na popularności oświatowy bon organizacyjny, jako narzędzie opracowane z myślą o optymalizacji struktury zatrudnienia w szkołach celem podźwignięcia ich z ekonomicznej zapaści, tylko pozornie sprzyja poprawie warunków kształcenia. Niekiedy przynosi efekt odwrotny. Bardzo często wzbudza niepokój wśród nauczycieli, także filologów, którzy, obawiając się redukcji zatrudnienia, rezygnują z awansu zawodowego, aby podnieść swoje szanse zatrudnienia w innych placówkach. Dochodzi tu do paradoksu, gdyż nauczyciel z niższymi kwalifikacjami ma, w obliczu rachunku ekonomicznego tak istotnego dla dyrektora szkoły, w rzeczywistości większe szanse na zatrudnienie niż ten, który osiągnął najwyższy stopień awansu. W przypadku redukcji etatów nauczyciele podejmują pracę w kilku szkołach jednocześnie, co wytrąca z nich zapał, uniemożliwia zupełne poświęcenie się swojej misji, choćby ze względów czasowych i logistycznych (por. Tobor, 2012: 98-n.).

Niedostatecznie zweryfikowany w warunkach polskich jest natomiast bon oświatowy, rozumiany jako forma finansowania szkół. Mechanizm, będący próbą urynkowienia, swoistej komercjalizacji placówek oświatowych na danym obszarze, wyraża się w formule, że bogatsza oferta programowa i lepsza jakość kształcenia czyni szkołę konkurencyjną, wzmaga popyt na jej usługi, a tym samym zapewnia jej finansowanie za pośrednictwem bonów, którymi dysponują uczniowie i które wyrażają wymierne środki finansowe. Pionierski charakter tego mechanizmu, pomimo pozytywnych opinii społeczności gmin, w których udało się go wdrożyć, wzbudza z kolei niepewność większości władz oświatowych i samorządowych. Dodatkowo rozkwit placówek niepublicznych, 
w pewnym stopniu elitarnych, nie pozostaje bez wpływu na społeczną ocenę działalności szkół publicznych, które, podlegając stałej krytyce i ulegając silniejszej konkurencji, stają się mniej przyjazne i mało innowacyjne - jak gdyby metodą negatywnej projekcji. Wszystko to dotyczy również kształcenia obcojęzycznego, a więc i nauczycieli specjalizujących się w takim kształceniu.

\section{Zakończenie}

Za podsumowanie powyższych rozważań niech posłużą zacytowane poniżej słowa Christophera Day'a (2004: 17-18), angielskiego specjalisty w dziedzinie rozwoju zawodowego nauczycieli. Na poziomie rozważań teoretycznych z jego tezami trudno się nie zgodzić, jednak, jak pokazuje praktyka edukacyjna, zwłaszcza ta realizowana w polskich szkołach konwencjonalnych, sposoby interpretacji i systemowej implementacji takich czy podobnych postulatów bywają bardzo zróżnicowane i niestety nie zawsze trafne. Nie są przy tym bez znaczenia deficyty świadomości, a niekiedy i motywacji, jakie $w$ dalszym ciągu w zakresie własnego rozwoju zawodowego prezentuje część nauczycieli języków obcych w Polsce. Bardzo często zapominają oni bowiem, że żaden system nie zmieni się na lepsze szybko i skutecznie, jeśli tworzące go ogniwa, a więc także oni sami, pozostaną skostniałe i nie będą przejawiać inicjatywy do zmian. Warto zatem przypomnieć, że:

1. „Nauczyciele są największym atutem szkół. Pośredniczą oni w przekazywaniu wiedzy, umiejętności oraz wartości. Nauczyciele będą mogli realizować swoje cele edukacyjne tylko wtedy, gdy będą dobrze przygotowani do zawodu i gdy będą w stanie utrzymać, a nawet zwiększyć swój potencjał poprzez uczenie się przez całą swoją karierę. Zatem wspieranie ich pomyślności i rozwoju zawodowego jest integralną i zasadniczą częścią wysiłków na rzecz podnoszenia jakości nauczania i uczenia się oraz polepszania ich wyników.

2. Jednym z głównych zadań wszystkich nauczycieli jest wpojenie swoim uczniom skłonności do uczenia się przez całe życie. Zatem muszą oni demonstrować własne zaangażowanie i entuzjazm dla takiego uczenia się.

3. Ciągły, trwający przez całą karierę, rozwój zawodowy jest konieczny, by dotrzymywać kroku zmianom oraz dokonywać rewizji i uaktualniać własną wiedzę, umiejętności i wizję tego, czym jest dobre nauczanie.

4. Nauczyciele uczą się w sposób naturalny w ciągu całej swojej kariery. Jednakże uczenie się tylko na podstawie doświadczenia ostatecznie ogranicza rozwój. 
Rozwój zawodowy nauczycieli języków obcych szkół państwowych niższego...

5. Przemyślenia i działania nauczycieli to rezultat wzajemnego oddziaływania historii ich życia, obecnej fazy rozwoju, otoczenia klasowego i szkolnego oraz szerszych społecznych i politycznych kontekstów, w jakich pracują.

6. Uczniowie różnią się motywacjami, podejściem do nauki, zdolnościami i pochodzeniem. Zatem nauczanie jest procesem złożonym. Chociaż złożoność ta może zostać zmniejszona, na przykład poprzez odpowiednie przygotowanie otoczenia, efektywne nauczanie zawsze będzie wymagało zarówno intrapersonalnych, jak i interpersonalnych umiejętności, a także osobistego i zawodowego zaangażowania, a więc połączenia odpowiednich myśli i uczuć.

7. Sposób, w jaki rozumiany jest program nauczania, ma związek z kształtowaniem przez nauczycieli ich osobistych i zawodowych tożsamości. Zawartość programowa i wiedza dydaktyczna nie mogą zatem być oddzielone od potrzeb osobistych i zawodowych ani celów moralnych danego człowieka. Wynika z tego, że rozwój zawodowy musi być z nim ściśle związany.

8. Nauczycieli nie można rozwijać. Oni rozwijają się sami. Muszą oni być głęboko zaangażowani w podejmowanie decyzji dotyczących kierunku i procesów własnego uczenia się.

9. Sukces rozwoju szkoły zależy od sukcesu rozwoju nauczyciela.

10. Za planowanie i wspieranie rozwoju przez całą karierę są wspólnie odpowiedzialni nauczyciele, szkoły, rządy".

\section{BIBLIOGRAFIA}

Day, C. 2004. Rozwój zawodowy nauczyciela. Uczenie się przez całe życie. Gdańsk: Gdańskie Wydawnictwo Psychologiczne.

Gębal, P. E. 2013. Modele kształcenia nauczycieli języków obcych w Polsce i w Niemczech. W stronę glottodydaktyki porównawczej. Kraków: Księgarnia Akademicka. Jaroszewska, A. 2009. Analiza kompetencji nauczycieli języków obcych w kontekście nauczania w różnych grupach wiekowych (w) Pawlak M., Mystkowska-Wiertelak A., Pietrzykowska A. (red.), Nauczyciel języków obcych dziś i jutro. Poznań-Kalisz: Wydział Pedagogiczno-Artystyczny UAM w Poznaniu, s. 83-93.

Jaroszewska, A. 2014. Budowanie przyjaznego środowiska wspierajqcego efektywnq naukęjęzyków obcych. Poradnik nie tylko dla nauczycieli. Ośrodek Rozwoju Edukacji i Centrum Kształcenia Nauczycieli Języków Obcych i Edukacji Europejskiej Uniwersytetu Warszawskiego, Warszawa [online: http://www.bc.ore.edu.pl/dli$\mathrm{bra} /$ docmetadata?id=590\&from=latest; DW: 30.01.2015].

Pfeiffer, W. 2001. Nauka języków obcych. Od praktyki do praktyki. Poznań: Wydawnictwo WAGROS. 
Tobor, M. 2012. „Lokalne standardy zatrudnienia w oświacie” (w) Finansowanie oświaty. Biblioteczka Oświaty Samorzqdowej. Tom 3 (red. M. Herbst). Warszawa: Ośrodek Rozwoju Edukacji: 98-128. [siedmiotomowy cykl publikacji dostępny również na stronie internetowej ORE].

Zawadzka, E. (2004). Nauczyciele języków obcych w dobie przemian. Kraków: Oficyna Wydawnicza „Impuls”.

\section{Wybrane akty normatywne:}

Rozporządzenie Ministra Edukacji Narodowej i Sportu z dnia 19 lutego 2002 r. w sprawie sposobu prowadzenia przez publiczne przedszkola, szkoły i placówki dokumentacji przebiegu nauczania, działalności wychowawczej i opiekuńczej oraz rodzajów tej dokumentacji (Dz.U. nr 23 z 2002 r., poz. 225 z późn. zm.).

Rozporządzenie Ministra Edukacji Narodowej i Sportu z dnia 29 marca 2002 r. w sprawie sposobu podziału środków na wspieranie doskonalenia zawodowego nauczycieli pomiędzy budżety poszczególnych wojewodów, form doskonalenia zawodowego dofinansowywanych ze środków wyodrębnionych w budżetach organów prowadzących szkoły, wojewodów, ministra właściwego do spraw oświaty i wychowania oraz szczegółowych kryteriów i trybu przyznawania tych środków (Dz.U. nr 46 z 2002 r., poz. 430).

Rozporządzenie Ministra Edukacji Narodowej z dnia 30 czerwca 2006 r. w sprawie standardów kształcenia nauczycieli w kolegiach nauczycielskich i nauczycielskich kolegiach języków obcych (Dz.U. nr 128 z 2006 r., poz. 897).

Rozporządzenie Ministra Edukacji Narodowej z dnia 12 marca 2009 r. w sprawie szczegółowych kwalifikacji wymaganych od nauczycieli oraz określenia szkół i wypadków, w których można zatrudnić nauczycieli niemających wyższego wykształcenia lub ukończonego zakładu kształcenia nauczycieli (Dz.U. nr 50 z 2009 r., poz. 400 z późn. zm.).

Rozporządzenie Ministra Edukacji Narodowej z dnia 7 października 2009 r. w sprawie nadzoru pedagogicznego (Dz.U. nr 168 z 2009 r., poz. 1324 z późn. zm.).

Rozporządzenie Ministra Nauki i Szkolnictwa Wyższego z dnia 17 stycznia 2012 r. w sprawie standardów kształcenia przygotowującego do wykonywania zawodu nauczyciela (Dz.U. nr 0 z 2012 r., poz. 131).

Rozporządzenie Ministra Edukacji Narodowej z dnia 7 lutego 2012 r. w sprawie ramowych planów nauczania w szkołach publicznych (Dz.U. nr 0 z 2012 r., poz. 204).

Rozporządzenie Ministra Edukacji Narodowej z dnia 27 sierpnia 2012 r. w sprawie podstawy programowej wychowania przedszkolnego oraz kształcenia ogólnego w poszczególnych typach szkół (Dz.U. nr 0 z 2012 r., poz. 977 z późn. zm.).

Rozporządzenie Ministra Edukacji Narodowej z dnia 21 grudnia 2012 r. w sprawie kryteriów i trybu dokonywania oceny pracy nauczyciela, trybu postępowania odwoławczego oraz składu i sposobu powoływania zespołu oceniającego (Dz.U. nr 0 z 2012 r., poz. 1538).

Rozporządzenie Ministra Edukacji Narodowej z dnia 1 marca 2013 r. w sprawie uzyskiwania stopni awansu zawodowego przez nauczycieli (Dz.U. nr 0 z 2013 r., poz. 393). 
Rozwój zawodowy nauczycieli języków obcych szkół państwowych niższego...

Ustawa z dnia 26 stycznia 1982 r. Karta Nauczyciela (Dz.U. nr 97 z 2006 r., poz. 674 z późn. zm.). Ustawa z dnia 7 września 1991 r. o systemie oświaty (Dz.U. nr 95 z 1991 r., poz. 425 z późn. zm.).

\section{Netografia:}

Alliance Française [http://institutfrancais.pl/pl/]

Baza obowiązujących i projektowanych aktów prawnych dotyczących systemu edukacji

[http://bip.men.gov.pl/index.php?option=com_content\&view=category\&layou $\mathrm{t}=$ blog\&id=26\&ltemid $=49$ ]

Biblioteka Cyfrowa Ośrodka Rozwoju Edukacji [http://www.bc.ore.edu.pl/dlibra]

British Council [http://www.britishcouncil.pl/]

Centralna Komisja Egzaminacyjna [http://www.cke.edu.pl/]

Czasopismo „Dyrektor Szkoły. Miesięcznik Kierowniczej Kadry Oświatowej” [http://www.

czasopisma.abc.com.pl/ds/]

Czasopismo „Edukacja i Dialog” [http://www.eid.edu.pl/aktualny_numer/]

Czasopismo „E-mentor” [http://www.e-mentor.edu.pl/]

Czasopismo „Języki Obce w Szkole. Czasopismo dla nauczycieli” [http://www.jows.pl/]

Czasopismo „Meritum. Mazowiecki Kwartalnik Edukacyjny” [http://meritum.mscdn.

$\mathrm{pl} / \mathrm{meritum} /]$

Czasopismo „Trendy - internetowe czasopismo edukacyjne” [http://www.ore.edu.pl/

strona-ore/index.php?option=com_content\&view=article\&id=2173\&/temid=1687]

Edukacja-Internet-Dialog - platforma internetowa [http://www.eid.edu.pl/]

e-Publikacje Nauki Polskiej [http://www.epnp.pl/]

European Language Label [http://www.ell.org.pl/]

European Profiling Grid (EPG) [http://www.epg-project.eu/]

Europejska baza projektów European Language Label [http://ec.europa.eu/education/language/label/label_public/index.cfm?lang=PL]

Europejski System Opisu Kształcenia Językowego [http://europass.cedefop.europa.eu/pl/resources/european-language-levels-cefr]

Europejskie Portfolio Językowe [http://www.ore.edu.pl/strona-ore/index.php?option= com_content\&view=article\&id=337\&Itemid=1059]

EURYDICE - Sieć Informacji o Edukacji w Europie [http://www.eurydice.org.pl/]

EURYPEDIA - European Encyclopedia on National Education System [https://webgate.

ec.europa.eu/fpfis/mwikis/eurydice/index.php?title=Home]

Fundacja Rozwoju Systemu Edukacji [http://www.frse.org.pl/]

Główne inicjatywy polityczne UE w zakresie kształcenia i szkoleń od 2000 roku - witryna

Komisji Europejskiej [http://ec.europa.eu/education/lifelong-learning-policy/po

licy-framework_en.htm]

Goethe-Institut [http://www.goethe.de/ins/pl/lp/plindex.htm]

Instituto Servantes [http://varsovia.cervantes.es/pl/default.shtm]

Instytut Badań Edukacyjnych [http://www.ibe.edu.pl/pl/]

Internetowy serwis informacyjny „Portal Oświatowy” [http://www.portaloswiatowy.pl/]

Internetowy System Aktów Prawnych [http://isap.sejm.gov.pl/index.jsp]

Istituto Italiano di Cultura [http://www.iicvarsavia.esteri.it/IIC_Varsavia] 
Języki i polityka językowa w UE - witryna Komisji Europejskiej [http://ec.europa.eu/languages/languages-of-europe/index_pl.htm]

Ministerstwo Edukacji Narodowej [http://www.men.gov.pl/]

Narzędzie EUROPASS [http://europass.cedefop.europa.eu/pl/home]

Österreichische Institut [https://www.warszawa.oei.org.pl/]

Ośrodek Rozwoju Edukacji [http://www.ore.edu.pl/]

Oświata - platforma internetowa Wydawnictwa Wolters Kluwer [http://www.oswiata .abc.com.pl/strona-glowna]

Podstawa programowa z komentarzami. Tom 3. Języki obce w szkole podstawowej, gimnazjum i liceum[http://www.men.gov.pl/images/ksztalcenie_kadra/podstawa/ men_tom_3.pdf]

Polski portal edukacyjny „Interkl@sa” [http://www.interklasa.pl/portal/index/strony] Portal „edulandia. pl” [http://www.edulandia.pl/edulandia/0,0.html]

Portal społeczności oświatowej „Oświata” [http://www.oswiata.org.pl/]

Portal wiedzy dla nauczycieli „Scholaris” [http://www.scholaris.pl/]

Program „Erasmus+"[http://erasmusplus.org.pl/]

Program „Uczenie się przez całe życie” [http://www.llp.org.pl/]

Program Kapitał Ludzki [http://www.efs.gov.pl/Strony/default.aspx]

Projekt FREPA - A Framework of Reference for Pluralistic Approaches/System opisu pluralistycznego podejścia do języków i kultur [http://carap.ecml.at/]

Publikacje UNESCO [http://www.unesco.org/new/en/unesco/resources/publications/]

Serwis edukacyjny „Profesor” [http://www.profesor.pl/] 